\section{Loyalitas Kreativitas \\ Aldi Masyarakat Kreatif}

P-ISSN 2722-2101, E-ISSN 2722-4201

Program Studi Ekonomi Manajemen Universitas Pamulang

Jurnal LOKABMAS Kreatif Vol.02,No.03.Nov 2021 Hal.46-51

Email:jurnalkreatif.manajemen@gmail.com

\title{
MEMBANGUN USAHA KREATIF DIKALANGAN PELAJAR
}

\author{
Fahmi Susanti ${ }^{1}$, Tiani Esa Sapitri ${ }^{2}$, Pudji Octavianti Lestari ${ }^{3}$, Hilda Indriani Millenia ${ }^{4}$, \\ Rohim Maulana ${ }^{5}$, Mumu Ahmad Mubarok $^{6}$ \\ 1Dosen Prodi Manajemen Fakultas Ekonomi Universitas Pamulang ${ }^{2,3,4,5}$ Mahasiswa \\ Manajemen Universitas Pamulang \\ Email : dosen02024@unpam.ac.id tianisapitri3@gmail.com pudjioctavianti@gmail.com \\ hildaindriani1312@gmail.com Maulanarohim21@gmail.com \\ mumuahmadmubarok30@gmail.com
}

\begin{abstract}
ABSTRAK
Pengabdian ini berjudul pelatihan dan mengajak anak anak untuk meningkatkan kreativitas di Yayasan Hidayatullah kelurahan bojongsari kota Depok. Metode yang digunakan adalah dalam bentuk penyampaian materi, presentasi, tanya jawab interaktif dan praktek membuat suatu produk yang mempunyai nilai jual. Kesimpulan dari pengabdian ini adalah peserta penyuluhan sudah memahami tetapi belum maksimal, hanya mengetahui materi dasarnya saja mengenai enterpreunership serta pentingnya kewirausahaan di era globalisasi. Tujuan pengabdian ini adalah memberikan edukasi kepada anak - anak Yayasan untuk lebih kreatif lagi apalagi saat masa pandemi covid - 19, agar lebih bisa memanfaatkan waktu luang juga untuk membuat sesuatu yang lebih bermanfaat dan ada nilai jual juga. Dan yang pasti bisa menambah wawasan baru untuk anak - anak Yayasan Hidayatullah
\end{abstract}

\section{Kata Kunci : Manajemen Pemasaran, Pemasaran}

\begin{abstract}
This service is entitled training and invites children to increase creativity at the Hidayatullah Foundation, Bojongsari Village, Depok City. The method used is in the form of material delivery, presentations, interactive question and answer and the practice of making a product that has a selling value. The conclusion of this service is that the counseling participants have understood but not maximized, only knowing the basic material about entrepreneurship and the importance of entrepreneurship in the era of globalization. The purpose of this service is to provide education to the children of the Foundation to be even more creative, especially during the covid-19 pandemic, so that they can take advantage of their free time to make something more useful and have a selling point. And that certainly can add new insights for the children of the Hidayatullah Foundation
\end{abstract}

Keywords : Keywords : Marketing Management, Marketing

\section{A. PENDAHULUAN}

Pengabdian masyarakat yang dilakukan oleh mahasiswa bukan berarti mengajar masyarakat tentang sesuatu yang terbaik untuk mereka, tetapi melakukan pemberdayaan sebagai sebuah proses pencarian (research) yang dilakukan bersamasama untuk mencari jalan terbaik dalam penyelesaikan persoalan yang mereka hadapi. Mahasiswa melakukan tugas pendampingan terhadap apa yang dibutuhkan oleh masyarakat dalam menghadapi problem sosial yang ada di tengah-tengah mereka. Pengabdian ini dilakukan di Yayasan 
Loyalitas Kreativitas Aldi Masyarakat Kreatif
Hidayatullah kelurahan Pondok Petir kota Depok. Analisis yang disampaikan adalah untuk menambah wawasan baru kepada anak - anak Yayasan Hidayatullah agar bisa memanfaatkan waktu luang untuk membuat hal - hal kreatif baru seperti membuat bouqet bunga, bros, tempat pensil, exploding box, dan masih banyak jenis kreatif lainnya, yang terbuat dari bahan utama kain flannel. Jenis kreatif yang dibuat ini sebenarnya bisa dimanfaatkan sebagai hadiah untuk seseorang, pada umumnya hadiah merupakan hal yang sangat diinginkan oleh setiap orang. Pengabdian Masyarakat merupakan kegiatan intrakurikuler yang memberi kesempatan kepada mahasiswa untuk belajar dan beketja bersama-sama dengan masyarakat.

Banyak bermacam-macam jenis hadiah yang ditawarkan sekarang ini, mulai dari jam, tas, baju, bunga dan sebagainya. Hadiah bunga contohnya yang bisa dibuat dengan kain flannel, bunga inipun dapat diberikan pada saat ulang tahun, wisuda, anniversary dan lain-lain. Tapi bunga asli biasanya tidak bertahan lama, dan ketika sudah layu bunga tersebut akan dibuang. Bunga tersebut tidak dapat dipajang dan dijadikan kenangkenangan. Hadiah tersebut lama kelamaan sudah dianggap biasa. Sekarang Orang-orang butuh hal kreatif yang dianggap beda dari yang lainnya. Oleh karena itu, orang-orang sekarang banyak mencari hal yang kreatif dan dapat bertahan lama. Disini kami membuat ide untuk menjual bouqet bunga yang menggantikan Bunga asli tersebut dengan bunga dari bahan flannel, dengan begitu bunga yang dijadikan sebagai hadiah tersebut dapat bertahan lama

\section{B.METODEPELAKSANAAN KEGIATAN}

Metode kegiatan yang digunakan adalah kita berkunjung dan bimbingan ke Yayasan Hidayatullah, Lokasi dari pelatihan ini Pondok Petir, Bojongsari, Depok. Pemaparan Materi pelatihan untuk membangun usaha muda oleh pelaksana pengabdian masyarakat dengan tema berwirausaha di kalangan remaja dan peran pengelolaan keuangan yang efektif dan efisien mendukung pengembangan usaha pada umumnya.
Di awal sesi pemateri memberikan beberapa pertanyaan sebagai bahan diskusi antara lain

1.Bagaimana cara memasarkan produk bagi para pemula usaha?

2.Apakah Sudah baik? Sudah sesuai rencana

? Sudah efisien ? Sudah Efektif?

3.Pentingkah strategi pemasaran dalah sebuah bisnis ?

\section{HASIL DAN PEMBAHASAN}

Peserta yang hadir sebanyak 10 Peserta didik yang terdiri dari perwakilan ketua Yayasan Hidayatullah serta para dosen dan Mahasiswa Universitas Pamulang. Kegiatan dilaksanakan melalui diskusi tanya jawab, dengan cara para narasumber memberikan penyuluhan dan diikuti oleh para peserta yang kumpul di halaman masjid Yayasan Hidayatullah yang antusias menyimak menggunakan sebuah laptop yang disambungan ke LCD. Kegiatan berjalan baik dan lancar, banyaknya peserta yang antusias untuk bertanya,berdiskusi dan praktek langsung menggunakan bahan bahan kerajinan tangan yang sudah disiapkan oleh panitia dan belajar menggunakan media sosial untuk mempromosikan produk melalui online yang menjadikan para nara sumber lebih bersemangat lagi untuk memberikan penyuluhan. Penggunaan teknologi digital berupa media sosial telah memengaruhi semua aspek termasuk aspek promosi usaha seperti para pelaku UMKM yang terus berjuang ditengah-tengah pandemi. Penggunaan media sosial diharapkan dapat digunakan sebagai salah satu pembuka semakin dikenal oleh dunia luas dan bisa membuka peluang usaha usaha baru usaha lain yang nantinya akan membuka usaha berdagang secara online untuk bekal dimasa yang akan datang. Dan kami juga memberi sedikit materi yang berhubungan dengan kewirausaha

\section{KEWIRAUSAHAAN}

\section{Pengertian Kewirausahaan :}

Kewirausahaan adalah sebuah proses dalam menciptakan sesuatu yang baru, dimana 
Loyalitas Kreativitas Aldi Masyarakat Kreatif proses dalam pengerjaannya dilakukan dengan kreatif dan penuh dengan inovasi. Tujuan dari kewirausahaan adalah untuk menciptakan sesuatu yang baru agar bermanfaat bagi orang lain serta memiliki nilai lebih.

Kewirausahaan merupakan sebuah sikap mental seseorang yang memiliki kreativitas yang tinggi. Seseorang yang memiliki jiwa kewirausahaan adalah orang yang aktif, unik, berdaya guna membuat sesuatu, serta bermanfaat bagi banyak orang. Kegiatan kewirausahaan memiliki proses yang dinamis demi menciptakan sesuatu yang disertai dengan model, sumber daya, waktu, serta risiko yang mungkin terjadi. Kewirausahaan merupakan proses dalam mengidentifikasi, mengembangkan dan mewujudkan visi dan misi usaha.

Ciri-ciri kewirausahaan :

Berikut ini adalah ciri-ciri orang yang memiliki jiwa kewirausahaan sebagai berikut:

1. Memiliki sifat kreatif dan berani

2. Berkemauan keras dan memiliki semangat yang tinggi

3. Mampu menganalisis dengan baik

4. Memiliki jiwa kepemimpinan dan tidak boros

5. Dapat membuat keputusan dengan bijak dan bertanggung jawab

6. Mengabdi pada bisnis yang dijalankannya

Tujuan Kewirausahaan :

Kewirausahaan merupakan kegiatan yang saat ini sudah banyak berkembang di Indonesia. sudah banyak yang mulai merintis usaha-usaha yang kreatif sehingga meningkatkan perekonomian di Indonesia. Berikut ini adalah tujuan kewirausahaan.

- Dapat membuka lapangan pekerjaan untuk orang lain .

- Menciptakan jaringan bisnis yang baru yang bisa menyerap banyak tenaga kerja di daerah asal

- Menularkan serta mengembangkan semangat berwirausaha pada orang lain .

Karakteristik Kewirausahaan :

1. Memiliki Sifat Yang Jujur

2. Disiplin

3. Kreatif dan Inovatif
4. Mempunyai Komitmen Tinggi

5. Mandiri dan Realistis

Manfaat Kewirausahaan :

1. Optimalkan Diri Sendiri

2. Optimis Untuk Bisa Membangun Usaha

Sendiri

3. Mencapai Keuntungan Dari Hasil Kerja

Keras

4. Menambah Lapangan Kerja Bagi Orang Lain

Ciri-Ciri Orang yang Punya Jiwa Kewirausahaan:

1. Mempunyai Keberanian Yang Tinggi

2. Mempunyai Semangat Tinggi dan Kemauan Keras

3. Mempunyai Daya Analisis yang Baik

4. Berjiwa Pemimpin dan Tidak Berperilaku Konsumtif

\section{Perencanaan Bisnis dalam 5W1H}

Di era modern ini peluang bisnis tidak hanya di dapatkan oleh mereka yang sudah dewasa atau mereka yang sudah memiliki gelar. Anak muda jaman sekarang pun juga banyak yang terjun ke dalam dunia bisnis. Dalam membuat bisnis tentu harus ada yang namanya $5 \mathrm{~W} 1$. perencanan pada dasarnya dapat dilihat dari perspektif $5 \mathrm{w}+1 \mathrm{H}$. Istilah ini memang lebih populer digunakan dalam jurnalisme, baik jurnalisme yang dikelola oleh media niaga maupun yang bersifat jurnalisme warga.

Pada jurnalisme, $5 \mathrm{~W}+1 \mathrm{H}$ digunakan sebagai salah satu kerangka besar untuk memetakan persoalan. Keenam elemen tersebut saling melengkapi. Kehilangan 1 elemen berita dapat menghilangkan fakta dan membuat informasi menjadi tidak lengkap. Secara umum, $5 \mathrm{~W}+1 \mathrm{H}$ mencakup :

(1) What (apa);

(2) Where (di mana/lokasi);

(3) when (kapan/waktu);

(4) Who (siapa/pelaku);

(5) Why (mengapa/sebab),

(6) How (bagaimana/proses).

KESIMPULAN DAN SARAN Kesimpulan 
Loyalitas Kreativitas Aldi Masyarakat Kreatif
P-ISSN 2722-2101, E-ISSN 2722-4201

Program Studi Ekonomi Manajemen Universitas Pamulang Jurnal LOKABMAS Kreatif Vol.02,No.02.Juli 2021 Hal.58-61 Email:jurnalkreatif.manajemen@gmail.com
Pelaksanaan kegiatan Pengabdian Kepada Masyarakat oleh Mahasiswa telah berjalan dengan lancar dan mendapat sambutan hangat dari tempat pelaksanaan kegiatan ini yaitu Yayasan Hidayatullah pondok petir. Harapan kami dengan pengabdian ini dapat membuka wawasan dari Yayasan Hidayatullah bojong sari, depok yang bermanfaat bagi anak anak. Materi yang kami berikan yaitu pendampingan dan pelatihan agar memberikan motivasi untuk berbisnis sejak dini serta dapat meningkatkan ekonomi dan keperibadian yang yang akan sangat bermanfaat dalam kehidupan mereka pada masa yang akan datang. Dalam laporan kegiatan ini mungkin banyak kekurangan yang ada, untuk itu kami berharap masukan dan kritikan dalam rangka perbaikan untuk kegiatan-kegiatan pengabdian masyarakat di masa yang akan datang. Semoga kegiatan pengabdian masyarakat ini dapat bermanfaat bagi masyarakat sekitar lingkungan Universitas Pamulang.

Saran

Berikut adalah beberapa saran untuk Yayasan Hidayatullah pondok petir setempat maupun masyarakat dalam meningkatkan potensi diri para peserta didik di Yayasan Hidayatullah pondok petir

1. Membuat akun media sosial sebagai media apabila berniat untuk membuka usaha 2. Penggunaan media social sangat bermanfaat untuk membuat sebuah inovasi atau sebuah usaha untuk memajukan kehidupan para peserta didik dalam memasarkan produk ataupun hal lain.

3. Usahakan setiap posting foto dan kegiatan yang berkaitan dengan Yayasan Hidayatullah pondok petir memberikan tanda pagar (hashtag) sebagai kata kunci dan tag ke akun akun yang mempunyai banyak follower.

4. Menjawab segala pertanyaan dari follower untuk menandakan bahwa akun aktif.

\section{DAFTAR PUSTAKA}

Elburdah, R. P., Pasaribu, V. L. D., Rahayu, S., Septiani, F., \& Metarini, R. R. A. (2021).

MOMPRENEUR

PENOPANG PEREKONOMIAN KELUARGA DI MASA PANDEMI
COVID-19 DENGAN BISNIS

ONLINE PADA KELURAHAN

PONDOK BENDA. Abdi Laksana:

Jurnal Pengabdian Kepada

Masyarakat, 2(1), 75-82

Susanti, F., Jaswita, D. I., \& Mardiana, S. (2020).

PENGEMBANGAN POTENSI

EKONOMI KEWIRAUSAHAAN IBU

RUMAH TANGGA DALAM

MENINGKATKAN EKONOMI

MASYARAKAT KELURAHAN

CEMPAKA PUTIH CIPUTAT. Jurnal

Lokabmas Kreatif: Loyalitas Kreatifitas

Abdi Masyarakat Kreatif, 1(1), 89-95.

Pasaribu, V. L. D., Agrasadya, A., Shabrina, N., \& Krisnaldy, K. (2020). Menjadi Enterpreneur Muda Yang Memiliki Jiwa Leadership Untuk Menghadapi Masa Depan. Abdi Laksana: Jurnal Pengabdian Kepada Masyarakat, 1(1).

Pasaribu, V. L. D., Susanti, F., \& Hartuti, E. T. K. (2019). Memotivasi Siswa dan Siswi SMK Letris Indonesia di Dalam Menentukan Pilihan Untuk Melanjutkan Pendidikan Atau Bekerja Setelah Lulus Sekolah. Jurnal Pengabdian Dharma Laksana, 1(2), 161-172.

Pasaribu, V. L. D., Sulaiman, S., Sutiman, S., Thaharudin, T., \& Purnomo, B. Y. (2020). Pengenalan Letak Posyandu Terdekat Dikelurahan Pisangan Dengan Manajemen Pemasaran Revolusi 4.0 Untuk Meningkatkan Pengetahuan Masyarakat Letak Dan Fungsi Posyandu Terdekat Pada Kelurahan Pisangan. Dedikasi Pkm, l(1), 105-110.

Pasaribu, V. L. D., Oktrima, B., Prabowo, B., Arianto, N., \& Haryoko, U. B. (2020). Progam Pendampingan Dan Penyelenggaraan Pendidikan Anak Pada Usia Dini Terhadap Prestasi Belajar Dilingkungan Rt 020 Rw 009. Kel Giri Peni. Kec Wates. Yogyakarta. Jurnal Lokabmas Kreatif, 1(1), 71-75.

Pasaribu, V. L. D., Jannah, M., Fazar, M., Putra, S. P., Monalisa, M., \& Sofa, M. (2021). MENINGKATKAN

PRODUKTIVITAS USAHA DIMASA PANDEMI PADA IBU PKK RT 
Loyalitas Kreativitas Aldi Masyarakat Kreatif
P-ISSN 2722-2101, E-ISSN 2722-4201

Program Studi Ekonomi Manajemen Universitas Pamulang Jurnal LOKABMAS Kreatif Vol.02,No.02.Juli 2021 Hal.58-61 Email:jurnalkreatif.manajemen@gmail.com
004/003 KELURAHAN SAWAH BARU CIPUTAT, TANGERANG SELATAN. Abdi Laksana: Jurnal Pengabdian Kepada Masyarakat, 2(2), 295-301

Pasaribu, V. L. D., Yuniati, H. L., Pranata, R., Sembayu, R., Purba, S. M., \& Nurbayani, T. T. A. (2021). MANAJEMEN KEUANGAN UNTUK MENGHADAPI DAN BERTAHAN DI ERA COVID 19. Jurnal Abdimas Tri Dharma Manajemen, 2(2), 12-18.

Pasaribu, V. L. D., Dwiyatni, A., Sabina, C., Ridwan, M., Gunawan, D. D., \& Noviani, B. C. (2021). EVALUASI PENERAPAN $3 \mathrm{M}$ DIMASA PANDEMIC COVID 19. Jurnal Abdimas Tri Dharma Manajemen, 2(2), 54-60.

Pasaribu, V. L. D., Syafei, A. N., Farhan, A., Aufaizah, A., Irani, C., \& Firtiayani, S. R. (2021). PENGARUH DISPLIN PROTOKOL TERHADAP KESEHATAN PENULARAN VIRUS COVID19. Jurnal Abdimas Tri Dharma Manajemen, 2(2), 91-98.

Pasaribu, V. L. D., Septiani, F., Rahayu, S., Lismiatun, L., Arief, M., Juanda, A., ... \& Rahim, R. (2021). Forecast Analysis of Gross Regional Domestic Product based on the Linear Regression Algorithm Technique.

Pasaribu, V. L. D., Priadi, A., Anismadiyah, V., Rahayu, S., \& Maduningtias, L. (2021). PENYULUHAN KREATIF DAN INOVATIF MENINGKATKAN MUTU PRODUKSI UMKM DI DESA BELEGA KABUPATEN GIANYAR. Pro Bono Jurnal Pengabdian Kepada Masyarakat, 1(02).

Pasaribu, V. L. D. (2021). PELATIHAN BERBASIS ONLINE DI ERA COVID-19. Jurnal Abdimas Tri Dharma Manajemen, 2(3), 26-32.

Pasaribu, V. L. D., \& Setyowati, R. (2021). ADAPTASI KEHIDUPAN NEW

\begin{tabular}{lrr} 
NORMAL & PADA & MASA \\
PANDEMI & & COVID-19 \\
DIYAYASAN & \multicolumn{2}{r}{ PONDOK } \\
PESANTREN & DAN & PANTI \\
ASUHAN & NURUL & IKHSAN \\
KECAMATAN & SETU, & KOTA \\
TANGERANG & SELATAN. Jurnal \\
Lokabmas & Kreatif: & Loyalitas \\
Kreatifitas & Abdi & Masyarakat \\
Kreatif, 2(2), & 82-88.
\end{tabular}

Priadi, A., Pasaribu, V. L. D., Virby, S., Sairin, S., \& Wardani, W. G. (2020). Penguatan Ekonomi Kreatif Berbasis Sumber Daya Desa Dikelurahan Rempoa. Abdi Laksana: Jurnal Pengabdian Kepada Masyarakat, 1(3), 356-35

Susanti, F., Ratnawati, W., \& ivan Jazwita, D. (2020). Literasi Digital Facebook dan Whatsapp terhadap Motivasi Belajar Generasi Milenial. Jurnal Lokabmas Kreatif: Loyalitas Kreatifitas Abdi Masyarakat Kreatif, 1(2), 35-40.

Susanti, F., Lisdawati, L., Andini, R., Setiawan, R., \& Ratnawati, W. (2020). Menanamkan Jiwa dan Semangat Kewirausahaan Persaingan Menghadapi di Era Globalisasi pada Guru dan Orangtua Murid Bimbingan Belajar Bimba Pamulang Tangerang Selatan. DEDIKASI PKM, 1(1), 95-100.

Nurwita, N., Susanti, F., Permada, D. N. R., \& Oktrima, B. (2020). DAMPAK BURUK PEMAKAIAN MEDIA SOSIAL TERHADAP SEMANGAT DAN CAPAIAN BELAJAR SISWA SMP ARRAISIYAH PAMULANG". Jurnal Abdimas Tri Dharma Manajemen, I(1), 66-76.

Susanti, F., Lisdawati, L., Hulasoh, E., Malik, C. D., \& Fadillah, F. (2021). PELATIHAN DAN PEMBENAHAN MANAJEMEN KEUANGAN DAN ADMINISTRASI PADA YAYASAN NURUL IMAN Kelurahan Ciater Serpong Kota Tangerang Selatan. Pro Bono Jurnal Pengabdian Kepada Masyarakat, 1(01). 
P-ISSN 2722-2101, E-ISSN 2722-4201

Loyalitas Kreativitas

Aldi Masyarakat Kreatif
Program Studi Ekonomi Manajemen Universitas Pamulang Jurnal LOKABMAS Kreatif Vol.02,No.02.Juli 2021 Hal.58-61

Email:jurnalkreatif.manajemen@gmail.com

\section{FOTO DOKUMENTASI}
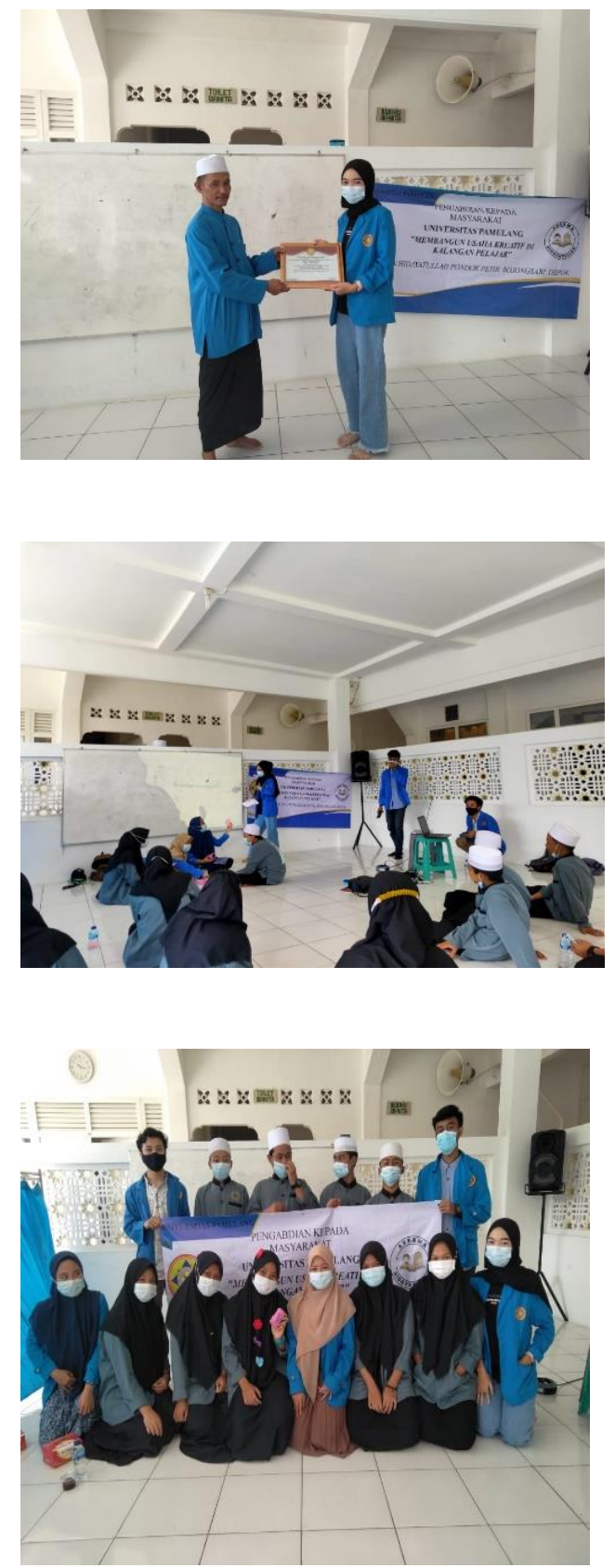